\title{
Article \\ Comparative Study of Ovule Development between Wild (Passiflora foetida L.) and Cultivated (P. edulis Sims) Species of Passiflora L. Provide Insights into Its Differential Developmental Patterns
}

\author{
Archa Vijay ${ }^{1}$, Ashifa Nizam ${ }^{1}$, Arun Madasseril Radhakrishnan ${ }^{1}$, Thattantavide Anju ${ }^{1}$ (D), Arun Kumar Kashyap ${ }^{2}$, \\ Nitesh Kumar ${ }^{3}$ and Ajay Kumar ${ }^{1, *(D)}$ \\ 1 Department of Plant Science, Central University of Kerala, Kasaragod 671316, Kerala, India; \\ archavijay1211@gmail.com (A.V.); ashifanizam94@gmail.com (A.N.); a.mr19k7@gmail.com (A.M.R.); \\ anjut609@gmail.com (T.A.) \\ 2 Department of Biotechnology, Government E. Raghavendra Rao Postgraduate Science College, \\ Bilaspur 495006, Chhattisgarh, India; akkbiotech@gmail.com \\ 3 Department of Biosciences, Himachal Pradesh University, Shimla 171005, Himachal Pradesh, India; \\ niteshchauhan7@gmail.com \\ * Correspondence: botanistajay@gmail.com; Tel.: +91-4672309245
}

Citation: Vijay, A.; Nizam, A.; Radhakrishnan, A.M.; Anju, T.; Kashyap, A.K.; Kumar, N.; Kumar, A. Comparative Study of Ovule Development between Wild (Passiflora foetida L.) and Cultivated ( $P$ edulis Sims) Species of Passiflora L. Provide Insights into Its Differential Developmental Patterns. J. Zool. Bot. Gard. 2021, 2, 502-516. https:// doi.org/10.3390/jzbg2030036

Academic Editor: Gianluigi Bacchetta

Received: 19 July 2021

Accepted: 14 September 2021

Published: 17 September 2021

Publisher's Note: MDPI stays neutral with regard to jurisdictional claims in published maps and institutional affiliations.

Copyright: (c) 2021 by the authors Licensee MDPI, Basel, Switzerland. This article is an open access article distributed under the terms and conditions of the Creative Commons Attribution (CC BY) license (https:// creativecommons.org/licenses/by/ $4.0 /)$

\begin{abstract}
The ovules inside the ovary of a plant are the precursors of seeds and they are important for the perpetuation of the plants. The genus Passiflora L., produce fruits with numerous seeds and they have economic and medicinal value. The edible portion of the Passiflora are the seeds surrounded by pulp. Being the edible parts of a fruit, it is important to investigate the early development of ovules in Passiflora that lead to the formation of seeds after pollination. Wild relatives of the domesticated crops are increasingly being investigated for possible genetic resources that can be used for crop improvement programs. The present study was designed to investigate the comparative ovule development between a wild (Passiflora foetida L.) and a cultivated (Passiflora edulis Sims) species of Passiflora with an aim that it may provide important information about the common and diverging regulatory mechanisms during ovule development between the wild and the cultivated species. We also investigated the pollen morphology between the wild and cultivated species using light and scanning electron microscopy. Our results show that wild type $P$. foetida ovule growth is faster when compared with that of cultivated P. edulis. Furthermore, wild species harbour ovules of large size $\left(0.14 \mathrm{~mm}^{2}\right)$ but less in number (6) as compared to cultivated ones which show smaller size $\left(0.05 \mathrm{~mm}^{2}\right)$ of ovules but relatively more in number (21). The differences in ovary wall thickness were also stark between the two species. The ovary wall thickness was $0.10 \mathrm{~mm}$ in the wild type whereas it was $0.74 \mathrm{~mm}$ in cultivated species. Notable differences were also observed in diameter where the wild type $(2.45 \mathrm{~mm})$ reported smaller diameter than cultivated species $(3.25 \mathrm{~mm})$. We observed little difference in the pollen morphology between the two species.
\end{abstract}

Keywords: ovule development; Passiflora; passion fruit; pollen morphology; Passifloraceae; Passiflora seeds

\section{Introduction}

The genus Passiflora is highly diverse and comprises around 550 known species, among which only 60 are edible [1]. The species of the genus are commonly known as the passion flowers [2,3]. Passiflora plants are generally shrubs or herbs and may produce bisexual or unisexual flowers [4,5]. Passion flowers are widely spread from tropical forests to high mountains in the Andes in the Neotropical region [6]. The plants are found in abundance in Brazil, Asia and Africa [1,7]. The Passiflora plants found in India are both naturalized and cultivated. They are predominantly found in the Western and Eastern Ghats and 
Eastern India. Most of the species produce edible fruits which have both commercial and medicinal values [3,8]. The species such as $P$. foetida L., P. caerulea L., P. incarnata L., P. setacea DC., P. trintae Sacco, P. cincinnata Mast., P. cristalina Vanderpl. \& Zappi, P. miniata Vanderpl., P. coccinea Aubl., P. cacao Bernacci \& M.M.Souza, P. glandulosa Cav., P. gibertii N.E. Br., P. mucronata Lam. are wild whereas species such as P. edulis Sims, P. alata Curtis, P. ligularis Juss., P. mollissima (Kunth) L.H.Bailey, P. maliformis L., P. quadrangularis L. are cultivated [9-11]. The different species of genus show a wide variation in leaves, flowers and fruits [12,13]. The P. edulis is widely consumed in various countries such as the Southern United States, Mexico, Central America, South America, North America, Southeast Asia and Australia and the Caribbean including India [14,15]. The fruits generally synthesize cyanogenic glycosides, alkaloids and flavonoids [16,17]. Passion fruits are rich in amino acids, minerals, unsaturated fatty acids, vitamin C, dietary fibre, B vitamins, niacin, iron, phosphorus and are also known for its medicinal properties [17-21]. The leaves are consumed as a green leafy vegetable in Sri Lanka [22]. The main attraction of the plant is the showy flowers and the distinctive corona [23]. The vines of the plant are climbers [24]. Passion flowers are protandrous and solitary by nature [25]. The receptacle bears the corona of the flower and nectar is secreted onto the receptacle [26]. The corona is brightly coloured and highly diverse among the various species and are especially important in the event of pollination to attract insect pollinators [27]. Styles are separate at the top and joined at the base and the stigmas clavate or peltate [28]. There are three bifurcated stigmas [25,29-31]. The androgynophore bears the superior and unilocular ovary $[15,32]$. The ovaries bear numerous anatropous ovules and show parietal placentation [33,34]. The fruits are indehiscent berries which are edible [35]. The plant has been used not only for the consumption of edible fruits but also for a wide variety of medicinal uses and ornamentation purposes [36]. Stamens are 3-5 in number and filaments are filiform, monadelphous or free and anthers are versatile [37].

Seeds are an important part of a plant required for the perpetuation of its generations. Its development takes place inside the fruits [38,39]. Studies show that the development of seeds is dependent on pollination and fertilization events which induce the transition of ovaries into fruits by the process known as the fruit set [40-42]. The studies on fruit development show that the developing ovules inside the ovary are paramount to the development of fruits and they also determine the size of fruits. Therefore, the quality and quantity of ovules is also dependent on ovule development [43]. Ovary size and seed number are important interconnect traits impacting yields. Several genes that determine gynoecium and ovule number have been identified over the period of time $[44,45]$. Several studies show that the fruit growth and development in various crops such as tomato [46], Vaccinium corymbosum L. (blueberry) [47], Capsicum annuum L. [48], Cucurbita pepo L. [49,50], Orchids [51], Solanum L. subg. Leptostemonum [52], Psidium guajava L. [53] and Opuntia Mill. spp. [54] are influenced by the number and size of seeds.

Ovules are developmental precursors of the future seeds [34]. Ovules develop inside the ovary, which is a part of the carpel involved in sexual reproduction [55]. It is the site where the haploid female gamete develops, fertilisation and embryo development takes place. Ovules consist of the nucellus, chalaza and funiculus [56]. Number and type of ovules differ in various species of the genus Passiflora $[57,58]$. Ovule development begins with the transition of the sporophytic phase to the gametophytic phase and ends with the formation of seed [59]. Ovule is the site of cross-communication between the maternal sporophytic and female gametophyte generations [60]. The ovule development is fairly studied in several species of flowering plants such as Asparagus officinalis L. [61], Arabidopsis Heynh. [62,63], Capsicum chinense Jacq. [64], Sedum sediforme (Jacq.) Pau [65], Corylus spp. L. [66], Clematis serratifolia Rehder [67], Jatropha curcas L. [68], Gossypium hirsutum Cav. [69]. Although many researchers have studied the ovule development in different species of plants, very little work on ovule development in Passiflora is available despite its huge economic and medicinal importance. This study provides a comparative overview of two species of Passiflora i.e., Passiflora foetida L. and Passiflora edulis Sims. Since pollen 
morphological analysis is important for taxonomic studies [70], we further compared the pollen morphology of the two species using light and scanning electron microscopy.

\section{Materials and Methods}

\subsection{Plant Acclimatisation and Growth}

For comparative study of ovule development in Passiflora, two species namely $P$. foetida and $P$. edulis were chosen. The wild species of $P$. foetida was collected from the Central University of Kerala Kasaragod premises whereas the cultivated P. edulis saplings was collected from a nursery in Kuniya (Kasaragod, Kerala, India). The plants were potted and acclimatised in the polyhouse at Central University of Kerala (Kasaragod, Kerala, India; $12.3929^{\circ} \mathrm{N}, 75.0917^{\circ} \mathrm{E}$ ). The maximum and minimum temperature of the region varies between 29.2 to $33.4^{\circ} \mathrm{C}$ and 19.7 to $25{ }^{\circ} \mathrm{C}$ respectively.

\subsection{Tissue Harvesting}

The development of ovules inside the ovary progresses simultaneously along with the ovary development before pollination and fruit development after pollination. To track the development of ovules, floral buds of various stages are collected from the acclimatized plants. Floral buds of stages 6, 7 and 8 (Figure 1 ) harvested 15 days, 10 days and 5 days before pollination respectively from each species were analyzed for both light microscopy and scanning electron microscopy.

(a)

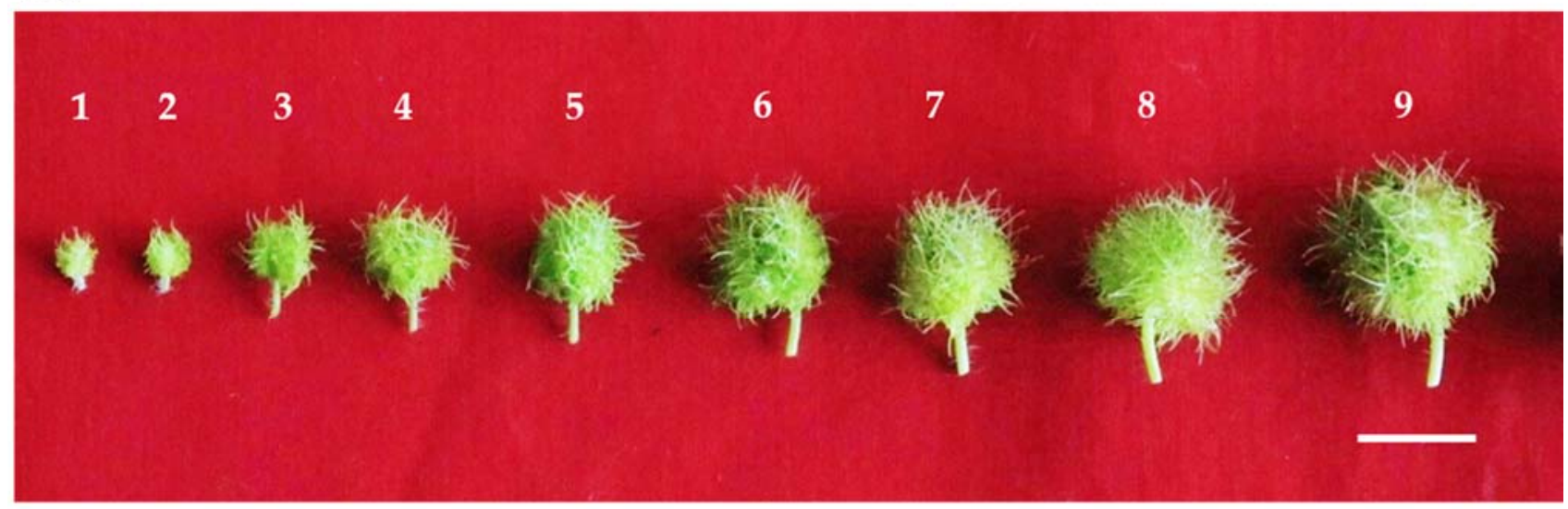

(b)

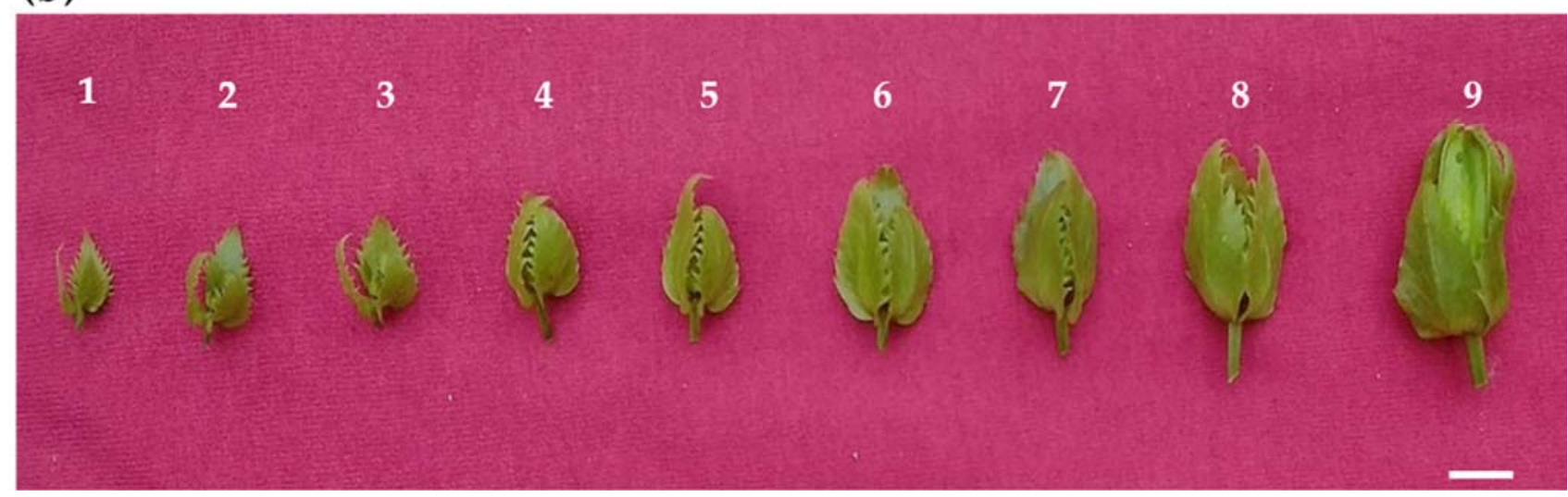

Figure 1. Morphological differences in developmental stages of the floral buds between (a) P. foetida (wild) and (b) P. edulis (cultivated) species considered for the ovule development study (scale bar $=1 \mathrm{~cm}$ ).

Three floral buds of each P. foetida and P. edulis were used for the analysis of ovary and ovule morphology. Six ovules were sampled at each developmental stage. The open flowers 
from both the species were collected to analyze the pollen grains. The buds were collected early in the morning and the histological sectioning was done immediately after collection.

\subsection{Histology and Staining}

For primary comparison of ovule development between both species, histological study is done by using light microscopy [71]. All collected flower buds were kept in formaldehyde-alcohol-acetic acid fixative in the ratio 2:17:1 [72]. The ovaries were separated carefully from the floral bud and the free hand histological sections were prepared. After preparing the histological sections, each section was placed in the safranin $\mathrm{O}$ stain for 5-6 s and excess stain was removed by washing followed by dehydration using a series of ethanol gradients $(10 \%, 20 \%, 30 \%, 50 \%$ and $70 \%)$ [73]. For the pollen analysis, dilute staining is preferred as the pollen gets stained faster. A single drop of safranin $\mathrm{O}$ stain was mixed with a drop of water and the pollen was dusted on the slide. The slides were observed under a Magnus light microscope (Magnus MLX-DX, Olympus Pvt. Ltd., Noida, Uttar Pradesh, India) and images were captured using Scope Photo software (Scope Photo Ver. 3.0).

\subsection{Scanning Electron Microscopy}

Scanning electron microscopy can be performed using acetolysis and non-acetolysis methods [74]. The scanning electron microscopy analysis was done using a non-acetolysis method [75]. The buds of different developmental stages were collected as described above and ovaries were separated from the bud and passed through the series of alcohol gradients for dehydration [76] and fixed by acetone [77]. The histological sections of the ovary were placed in the carbon conducting tape in the metal stubs and gold sputter coating was done using a sputter coater (SC7620, QUORUM Technologies, Lewes, UK). For pollen morphology, anthers were collected from the open flowers, and the pollen were dusted into the carbon tape fixed in the metal stub, and sputter coating was done [78]. The samples were then placed in the scanning electron microscope (VEGA3 SBH, TESCAN, Czech Republic), and images were taken.

\subsection{Measurement of Ovary and Ovule Characteristics}

The image analysis software ImageJ was used to measure ovary and ovule parameters [79]. Ovary wall thickness, perimeter, equatorial and polar diameter, ovule size (area), number of ovules per placenta and total number of ovules of both species were considered for the comparative analysis [80]. Image files of histological sections were opened in ImageJ. Scale was set with a scale bar from the image as reference. Straight line tool was used to calculate ovary thickness and diameter. For the measuring ovary perimeter and ovule area, a freehand line tool was used.

\section{Results}

\subsection{Morphological Differences between P. foetida and P. edulis}

In the present study, two species of Passiflora L., namely P. foetida and P. edulis were used for comparative investigation of ovule development and pollen morphology. Morphologically, the two species show considerable differences in their various characters. The $P$. foetida is a creeping vine, the flowers are small with white petals and dark pink corona, the three-lobed leaves are hairy and alternate. The tendrils are produced by the stem from the base of the leaves. The stems are thin and contain sticky hairs. The small, edible fruits are green when unripe and yellow when ripe. The size of fruits between the wild and the cultivated varies drastically. The wild $P$. foetida bears very small fruits as compared to cultivated P. edulis (Figure 2). The fruits are partially enclosed by the bracts that dry when the fruits mature. On the other hand, P. edulis flowers are large and showy with white petals and violet corona, the leaves are alternate ' $\mathrm{V}$ ' shaped and the stem is woody and have tendrils. The tendrils have a purple shade when young. The large, round fruits are green when unripe and can be yellow or purple when ripe (Figure 2). The nature of 
the pulp is similar in both species. Figure 3 represents morphological differences between plants of P. foetida and P. edulis. Three lobed leaves are present in both species while leaf size was smaller in P. foetida (Figure 4). We can easily distinguish between the two species from the size and shape of the leaves. The leaves in P. edulis have deeper incisions at the lobes.

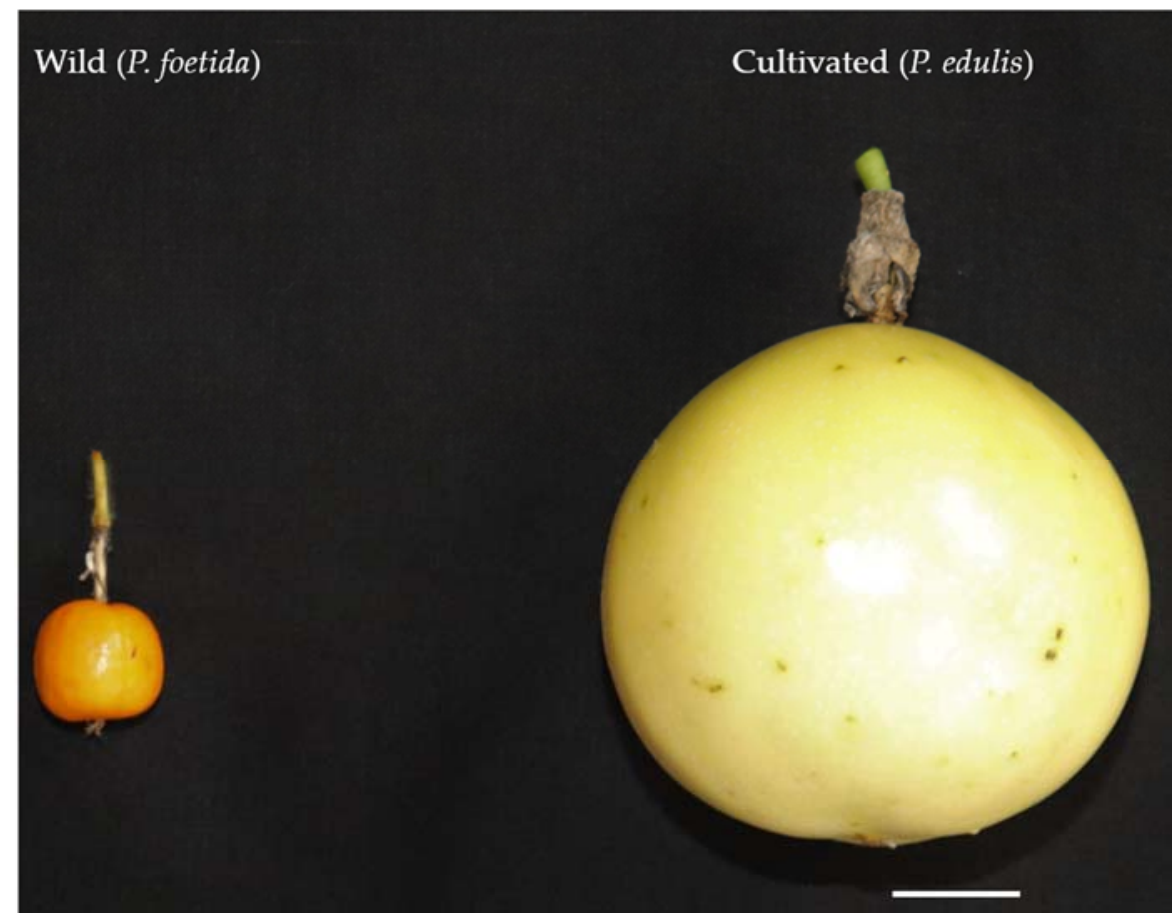

Figure 2. Differences in fruit morphology between P. foetida (wild) and P. edulis (cultivated; scale bar $=1 \mathrm{~cm}$ ). The size and colour differences are notable between the wild and cultivated species of Passiflora.
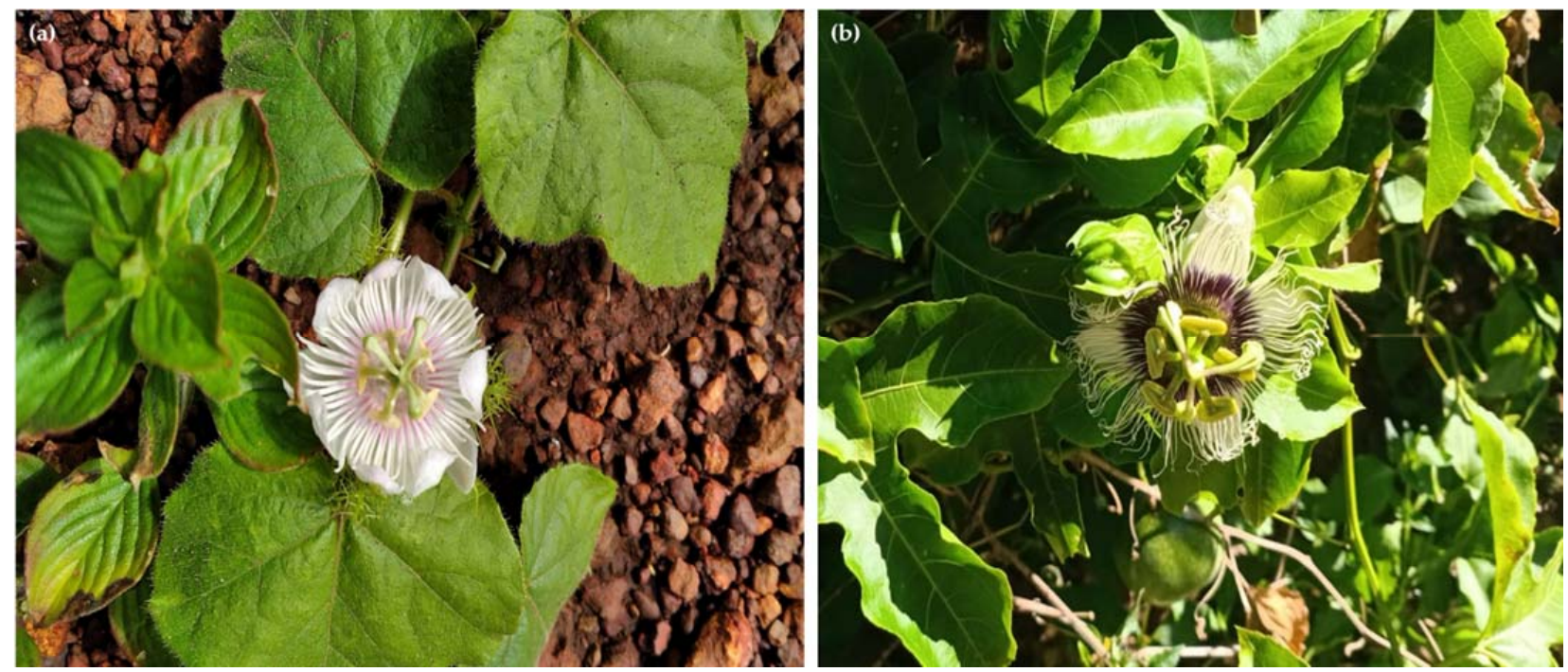

Figure 3. Morphological differences between a wild and a cultivated species of Passiflora L. (a) P. foetida and (b) P. edulis respectively. 


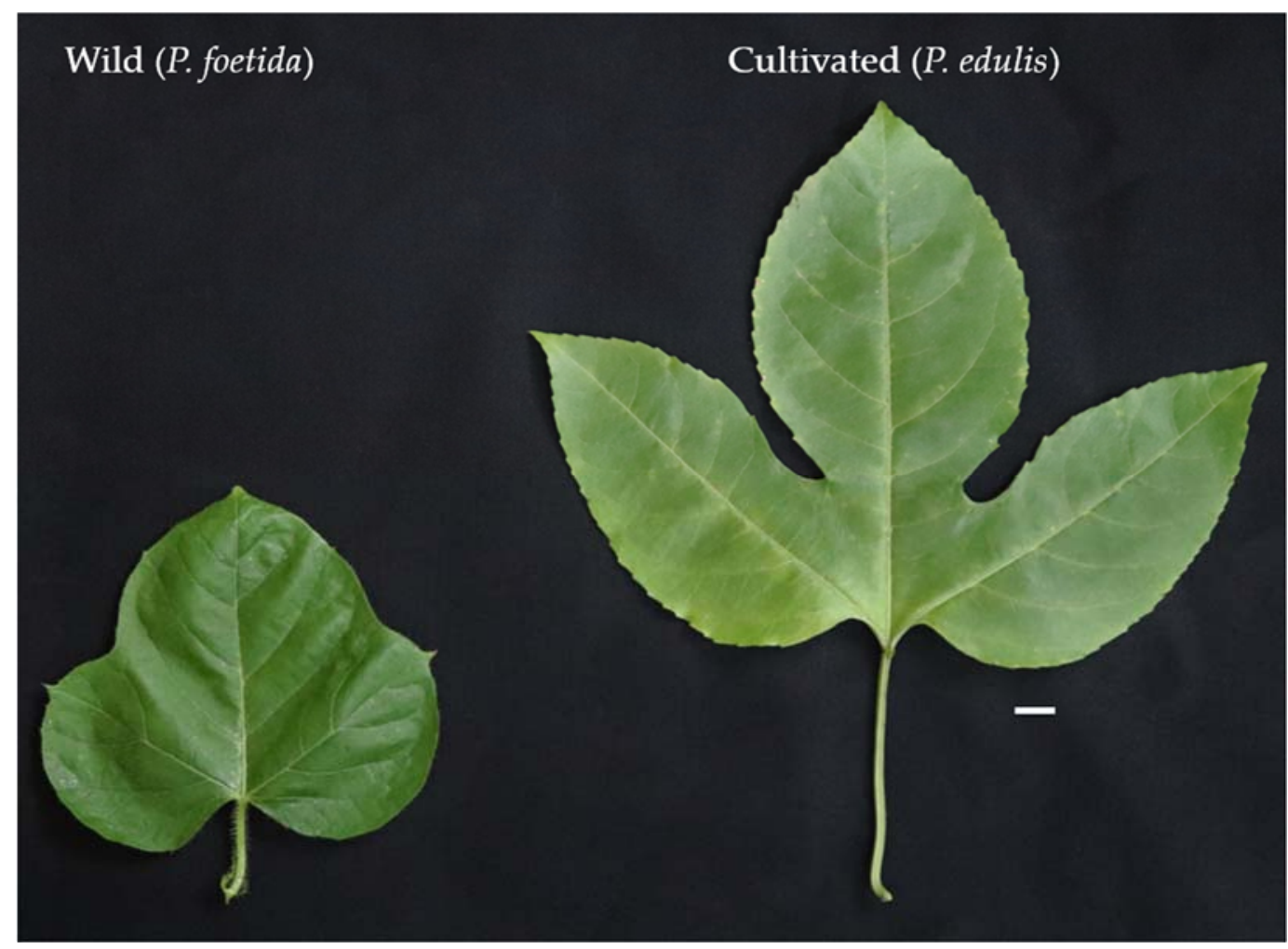

Figure 4. Leaf morphology in wild P. foetida and cultivated species P. edulis (scale bar $=1 \mathrm{~cm}$ ). Note the differences in leaf size and the lobe incisions.

\subsection{Floral Characterization of Two Species}

The flowers of $P$. foetida are covered by three reticulated green bracts. The veins of the bracts end with glandular structures that release adhesive ooze. The flowers are white and are borne singly. The flower has five petals and five sepals. They also have five stamens and an ovary topped with three style tipped with prominent stigmas. On the other hand, $P$. edulis flowers are larger in size and lack the presence of reticulate green bract. The flowers are hence non-glandular. The flowers have five white petals, five green sepals and a showy corona. The base of the flower has five stamens, an ovary and a branched style. Figure 5 shows floral differences between wild and cultivated species of Passiflora.
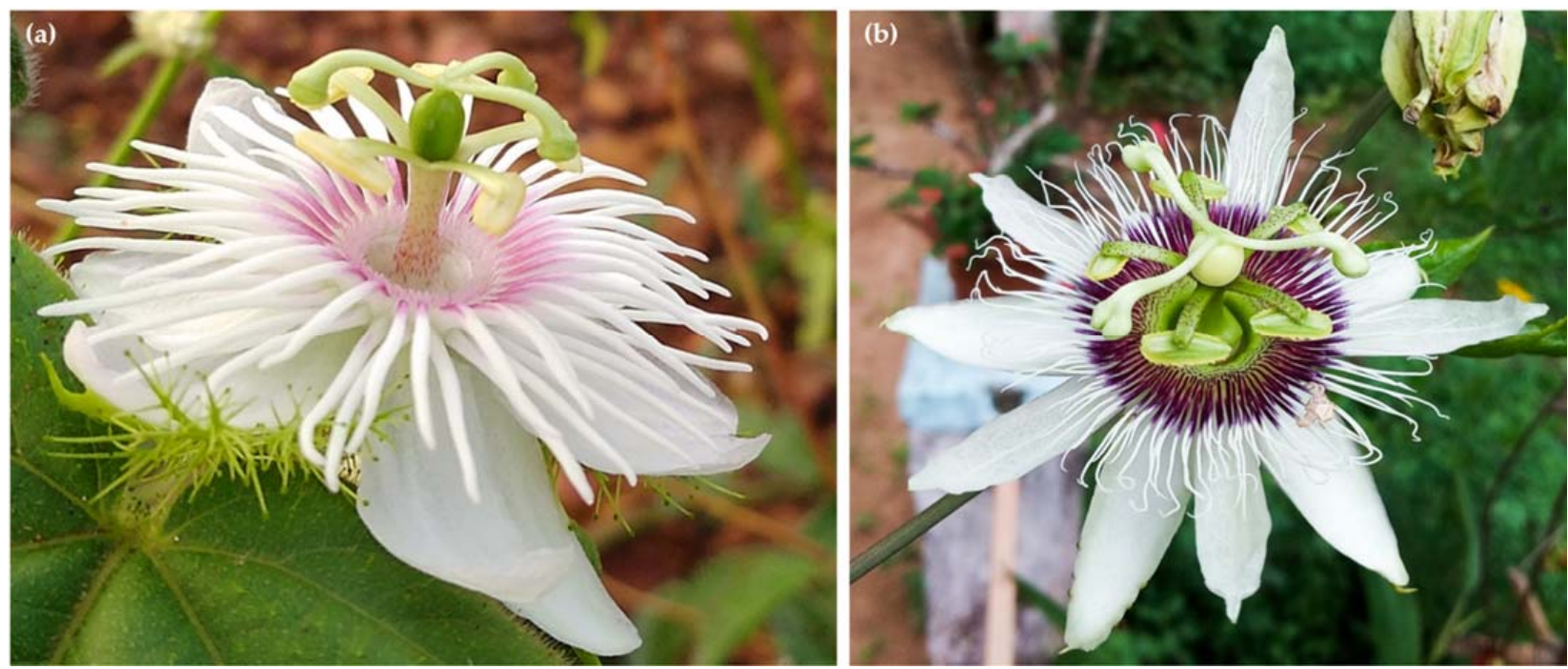

Figure 5. Difference in floral architecture between (a) P. foetida (wild) and (b) P. edulis (cultivated). 


\subsection{Ovule Development in Wild and Cultivated Species of Passiflora}

Floral buds were arranged in descending order of their sizes to isolate the ovaries for light and scanning electron microscopy analysis (Figure 1). To investigate the morphological differences in ovary, measurements were taken using ImageJ (Figure 6). Thickness of the ovary wall was less in wild type $P$. foetida $(0.10 \pm 0.012 \mathrm{~mm})$ when compared to its cultivated counterpart $P$. edulis $(0.74 \pm 0.177 \mathrm{~mm})$. Measurements of the ovary perimeter indicate P. foetida $(4.89 \pm 0.10 \mathrm{~mm})$ is smaller than P. edulis $(8.78 \pm 1.78 \mathrm{~mm})$. Length differences in equatorial and polar diameter are negligible, but variation is observed between the two species (Figure 6). The development of ovules in both the species start with small finger-like projections in the ovary walls. The wild and cultivated species show differences in the development of the ovules. The wild species P. foetida shows a very symmetric and definite distribution of ovules in its ovary. We observed that, P. foetida ovules are larger in size but less in number as compared to cultivated species P. edulis which has smaller ovules but more in number (Figures $7 \mathrm{a}-\mathrm{c}$ and $8 \mathrm{a}-\mathrm{c}$ ).

(a)

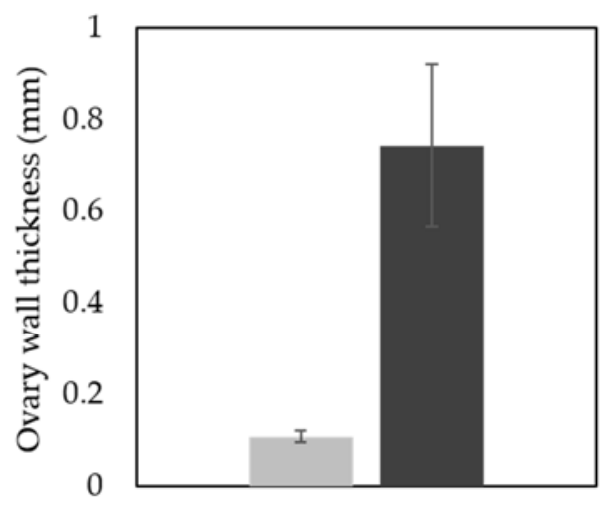

(c)

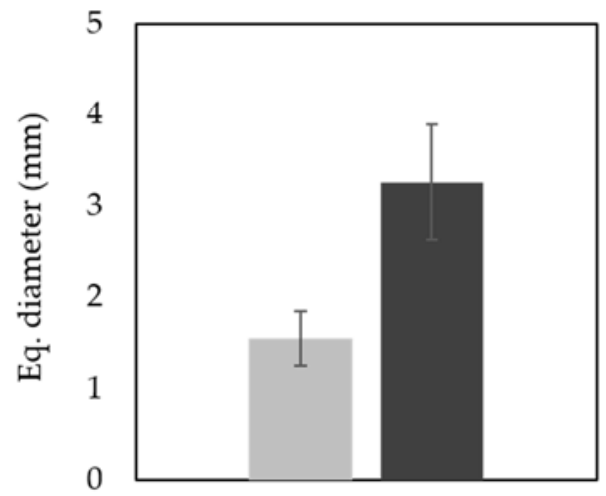

(b)

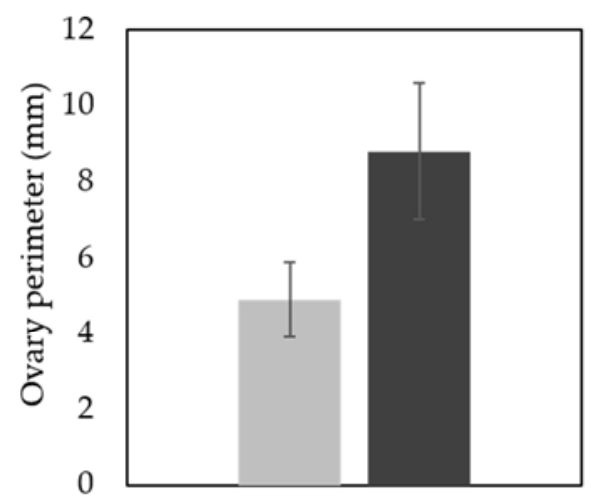

(d)

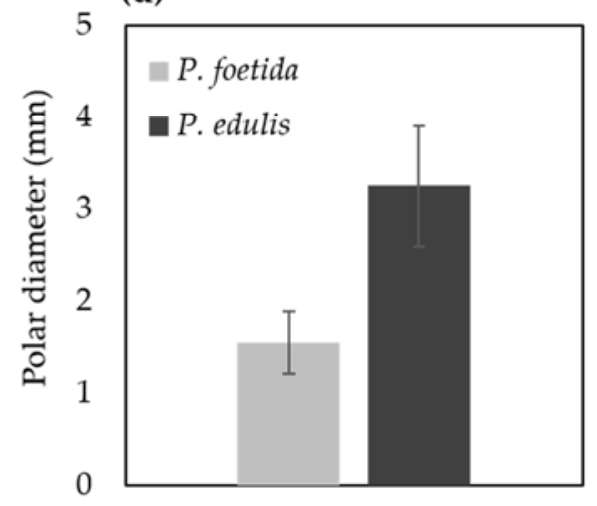

Figure 6. Micromorphological differences in the ovary of P. foetida (wild) and P. edulis (cultivated) species of Passiflora. (a) Ovary wall thickness, (b) perimeter, (c) Equatorial diameter and (d) Polar diameter. Data are mean \pm SE $(n=6)$. 

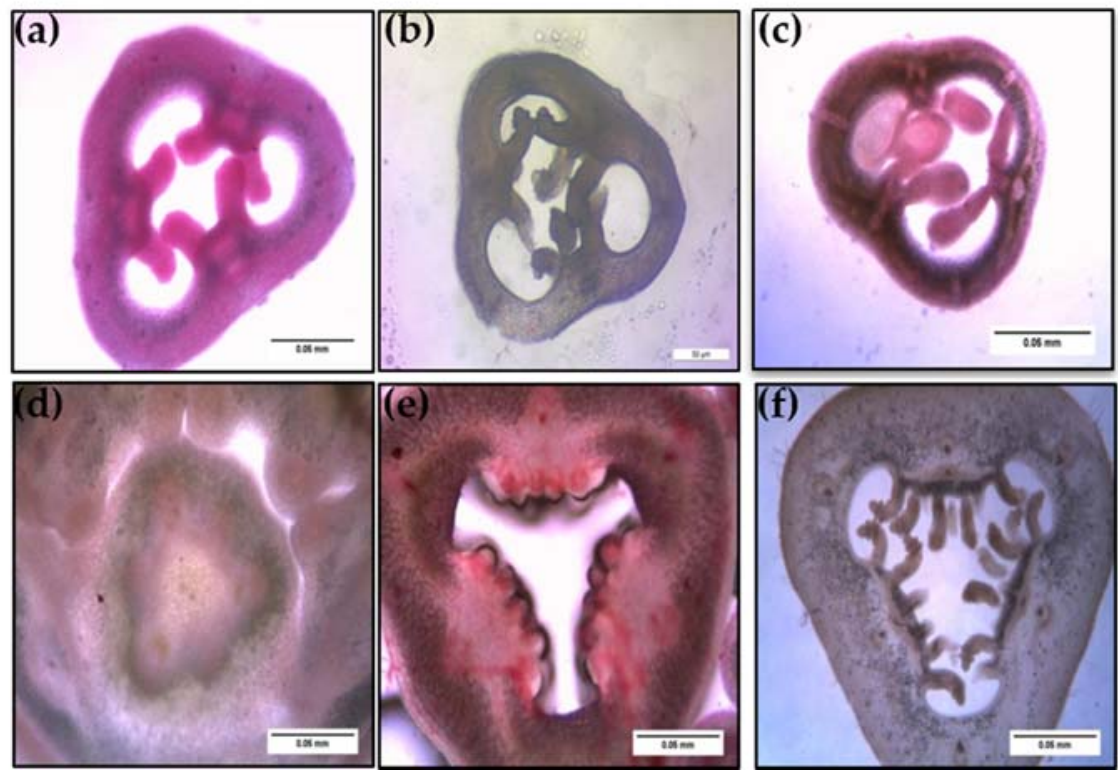

Figure 7. Histological observations of ovule development between a wild P. foetida (a-c) and a cultivated $P$. edulis $(\mathbf{d}-\mathbf{f})$ viewed under light microscope (scale bar $=0.05 \mathrm{~mm}$ ).
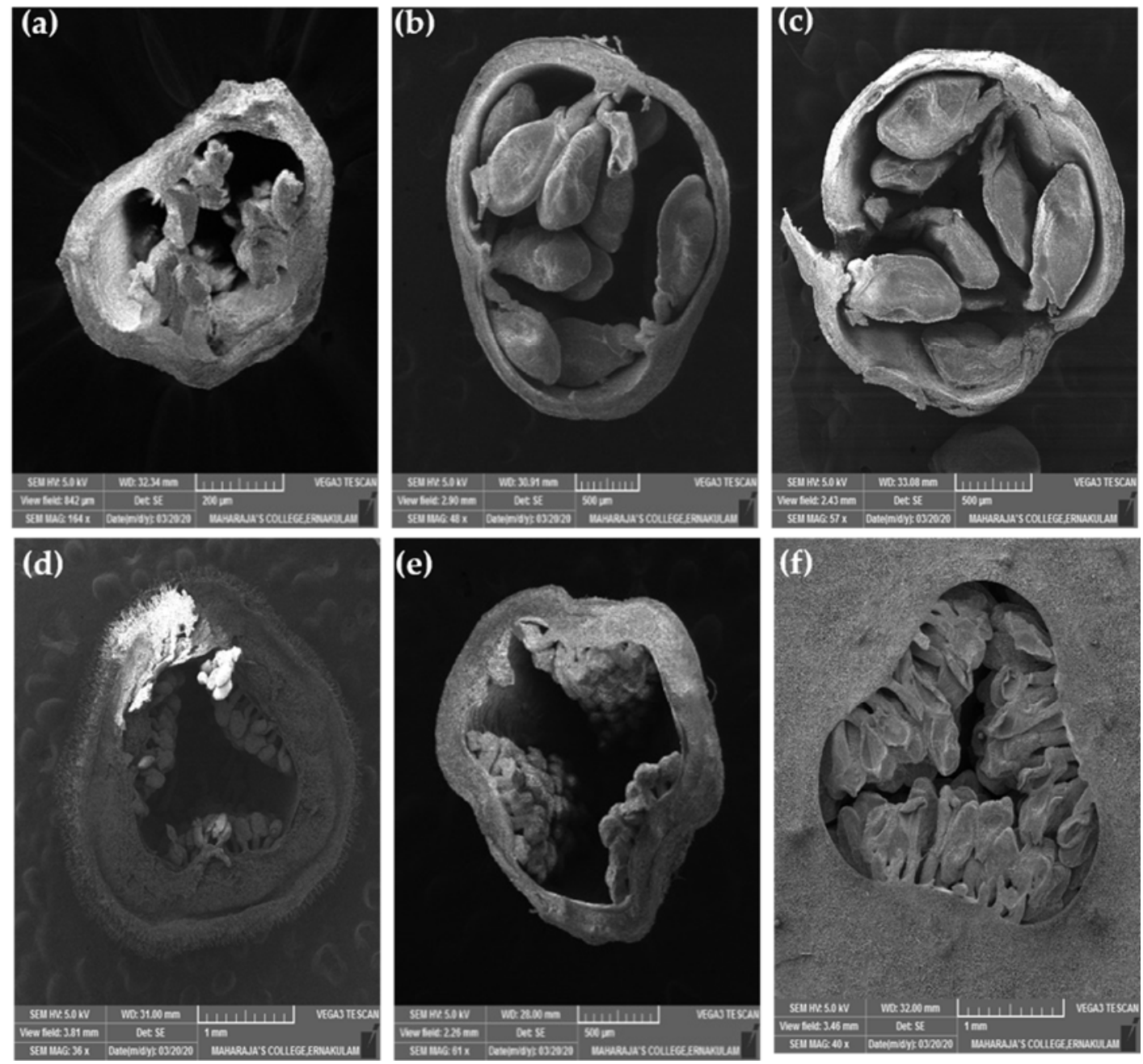

Figure 8. Ovules of a wild P. foetida $(\mathbf{a}-\mathbf{c})$ and a cultivated P. edulis $(\mathbf{d}-\mathbf{f})$ at different developmental stages viewed under scanning electron microscope. 
Ovule size was calculated as area in Image (Figure 9), which led to the findings that mean ovule area in P. foetida $\left(0.150 \pm 0.04 \mathrm{~mm}^{2}\right)$ was markedly greater than P. edulis $\left(0.053 \pm 0.016 \mathrm{~mm}^{2}\right)$. On the other hand, cultivated P. edulis shows a higher number of ovules which vary from fruit to fruit are however smaller in size (Figures $7 \mathrm{~d}-\mathrm{f}$ and $8 \mathrm{~d}-\mathrm{f}$ ). Ovule count per placenta for P. foetida and P. edulis is two and seven respectively (Figure 9). The differences in sizes of the ovules may be because of faster development of ovules in the $P$. foetida in contrast to $P$. edulis which shows a very slow growth rate of its ovules. The larger ovule size of the wild species (P. foetida) is not reflected in its fruit size.

(a)

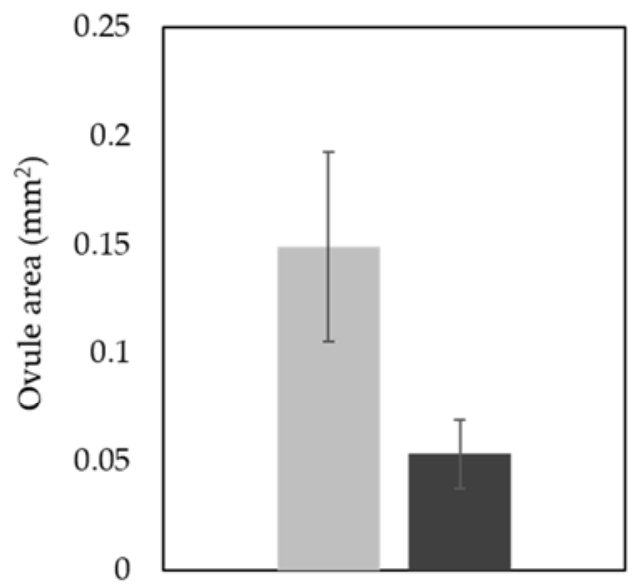

(c)

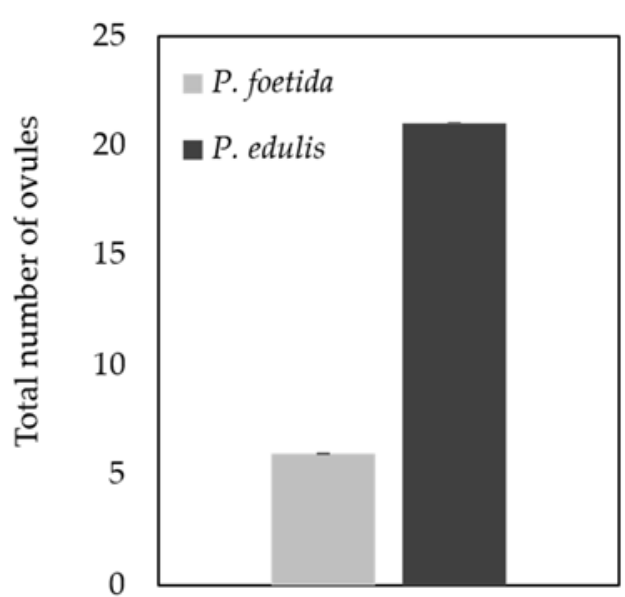

(b)

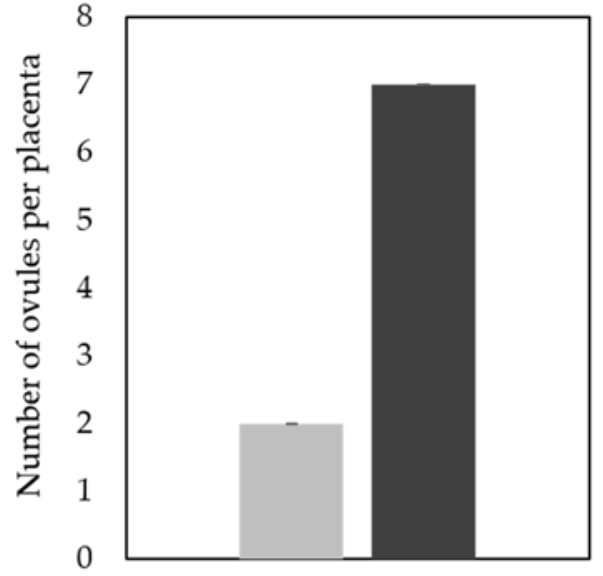

Figure 9. Size and number of ovules from P. foetida (wild) and P. edulis (cultivated). (a) Size, (b) Number of ovules per placenta and (c) Total number of ovules. Data are mean $\pm \operatorname{SE}(n=6)$.

\subsection{Pollen Morphology}

The pollen grains of P. foetida and P. edulis showed distinct ornamentation (Figure 10a-d). However, pollen grains of both species were oblate, spherical in shape with six colpi. The colpi were fused at the ends, hence forming syncolpate apertures. Reticulate exine is observed in both species. The similarity in characters explains the evolutionary conserved nature of the pollens between the two species. 

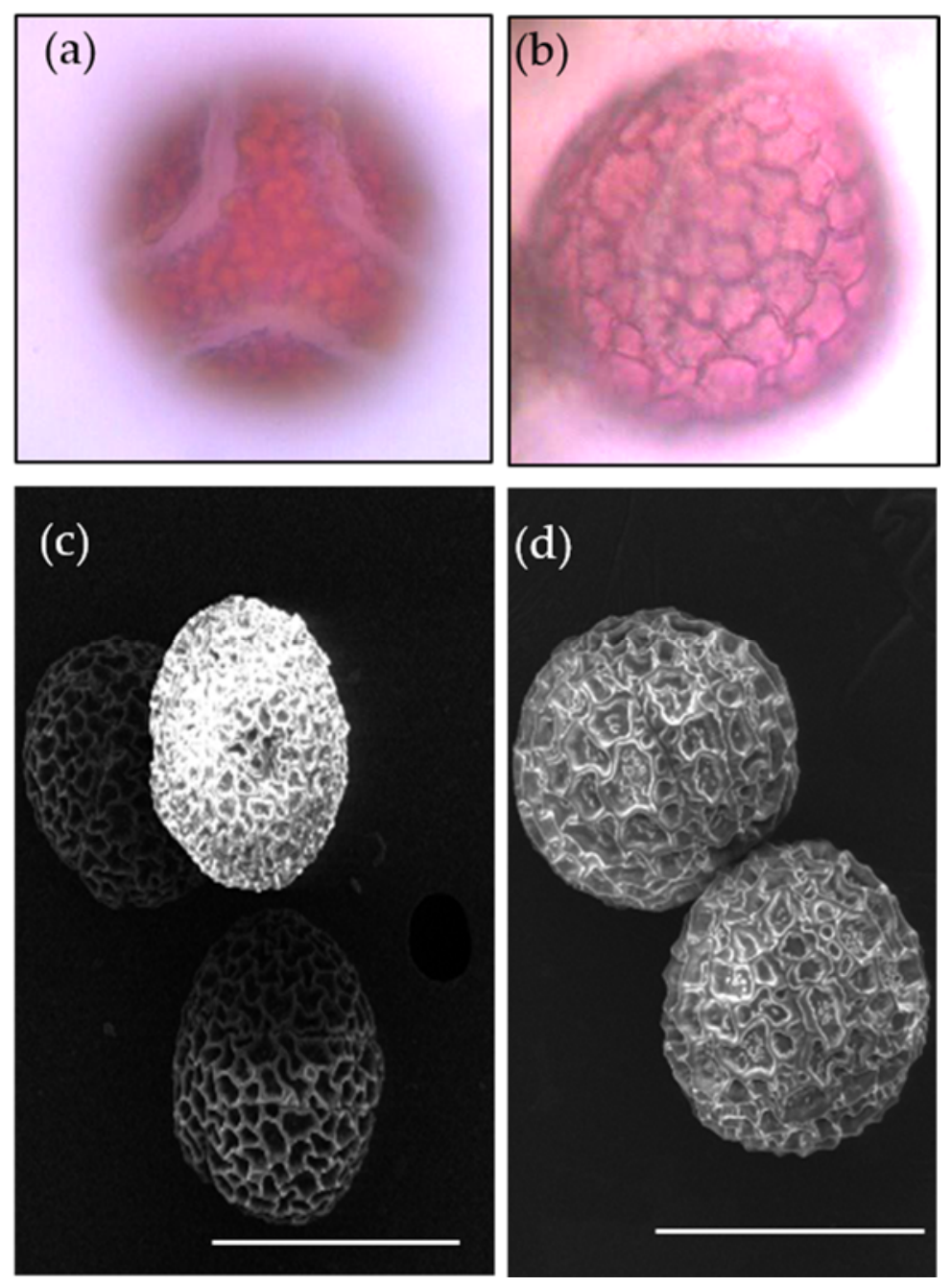

Figure 10. Pollen morphology of $P$. foetida $(\mathbf{a}, \mathbf{c})$ and $P$. edulis $(\mathbf{b}, \mathbf{d})$ viewed under light microscope and scanning electron microscope.

\section{Discussion}

\subsection{Differences between Wild and Cultivated Species of Passiflora}

The present study dealt with two species belonging to the genus Passiflora L. namely, P. foetida L. and P. edulis Sims. The P. foetida is a wild plant that grows abundantly in various terrains [4]. Both species show considerable morphological differences in the leaf shape, flower morphology, the habit of the plant and the fruit size (Figures 1-5). P. foetida has solid stem, tendrils, trifoliate leaves, eye-catching flowers and carries hairs all over the plant body. Leaves are single, alternate and hairy. Flowers have white colour outside and dark pink to violet colour inside. Each bud is covered by three highly reticulated green bracts and they cover the unopened buds and fruits completely [81]. On the other hand, P. edulis has perennial woody habit, tendrils, evenly serrated bracts, shorter corona than the calyx and bright purple, fleshy berry, ovoid or globose fruit. Its leaves are alternate and either horseshoe or ' $\mathrm{V}$ ' shaped. The flowers are large and showy and the petals are generally pale green and oblong. The corona is composed of two series of filiform filaments [82].

\subsection{Ovule Development in P. foetida and P. edulis}

The ovule development begins with the primordial initial, which later develops to form the ovule [34]. The ovule, developed within the ovary, is protected by integuments and has a stalk called funiculus that attaches the ovule to the ovarian placenta [83,84]. When it attains maturity, the ovule curves inwards and becomes anatropous [34]. When the 
ovary matures, it becomes the fruit, and the ovules develop into seeds [85]. As observed by Padhye and Deshpande [86], the ovules were anatropic and bitegmic. The studies conducted by various researchers on the ovules of the different plants suggest that the ovule arises as a finger-like projection [87]. The initials of the integuments also arise from the top portion of these projections $[34,86]$. The results show that the finger-like projections soon develop into ovules covered by two integuments.

\subsection{Ovule Size and Number between P. foetida and P. edulis}

We observed differences in the number and size of the ovules between wild $P$. foetida and cultivated P. edulis species. The rate of development of ovules was different in both the species and P. foetida had less number of ovules in comparison to P. edulis. The ovary diameter and ovary wall thickness was also different between the two species. The ovary diameter and ovary wall thickness in P. foetida was considerably lower when compared with $P$. edulis. Differences in the ovule number and size might be due tradeoffs for size and number between the two species [88]. However, it is important to note that the P. edulis which is a cultivated species might have been domesticated for its larger fruit and more number of the seeds inside it. It was surprising to observe bigger ovules inside a tiny fruit in P. foetida when compared with P. edulis. Another reason that explains increased size of the fruits in P. edulis may be due to the number of seeds inside the growing ovary. It has been reported from various species that the number of ovules inside the ovary directly affects the fruit size [44,89-91].

\subsection{Pollen Morphology}

The pollen characters help to identify and distinguish between the different species and help explain the phylogenetic relationships [92]. The pollen of P. foetida and P. edulis had an oblate, spherical shape and were hexacolporate. The hexacolporate structure of the pollen of $P$. foetida was also observed earlier by Padhye and Deshpande [86]. Our study did not notice much difference in the pollens between the wild (P. foetida) and cultivated (P. edulis) at the morphological level. However, study of pollens is important for further studies focusing on phylogenetic aspects of the family Passifloraceae.

\section{Conclusions}

This study is a preliminary investigation of differences in the development of ovules between the wild ( $P$. foetida) and cultivated ( $P$. edulis) species of Passiflora L. Our study provides an important insight on the differential developmental patterns between wild $P$. foetida and cultivated $P$. edulis species. The ovule development study shows that the number and size of ovules vary between the two species and this variation may prove to be associated with the mature size and yield related traits in the passion flowers besides various genes and other regulators. Further studies in the future must consider analysing the genetic basis of this variation. The proteome analysis from different species especially between wild and cultivated species of Passiflora at different developmental stages of their fruits will give important insights on proteomic regulation of fruit and ovule development. There are more than 500 species of Passiflora and many of them are edible and orphan crops in various parts of the world. They provide important genetic stocks for the crop improvement programs aimed at improvement of the $P$. edulis and other domesticated species. Availability of the crop wild relatives is an asset for the crop improvement programs and investigation of the genetic and molecular mechanisms that govern differences in the desirable traits is an important step towards this end. Future studies must be designed to explain the genetic and molecular mechanisms behind the differences in the ovule size, ovule number, and ovary size and ovule density between the wild and cultivated species. The genes from the wild species could be incorporated into commercially beneficial species that mature at a slow rate and the commercial value of such plants can be improved in future. 
Author Contributions: A.V. designed and conducted study, participated in data collection, analysis and drafted the manuscript. A.N. analysed the data and prepared the manuscript. A.M.R. participated in the design of the study, data collection and analysis. T.A. analysed and consolidated the data. A.K.K. analysed the data and prepared the draft of the manuscript. N.K. helped in data analysis and visualization. A.K. participated in the design of the study, analysis of data and preparation of manuscript. All authors have read and agreed to the published version of the manuscript.

Funding: This work was supported by Kerala State Council for Science, Technology and Education in the form of a student project under Grant No. 00496/SPS64/2019/KSCSTE.

Institutional Review Board Statement: Not applicable.

Informed Consent Statement: Not applicable.

Data Availability Statement: The data presented in this study are available on request from corresponding author.

Acknowledgments: Authors acknowledge the help provided by Central University of Kerala for the laboratory facilities and reagents and Jishnu and R. Manoj from Maharaja's College, Ernakulam, Kerala for the technical assistance with the scanning electron microscopy experiments.

Conflicts of Interest: The authors declare that there is no conflict of interest in this work.

\section{References}

1. Rodriguez-Amaya, D.B. Passion Fruits. In Encyclopedia of Food Sciences and Nutrition, 2nd ed.; Caballero, B., Ed.; Academic Press: Oxford, UK, 2003; pp. 4368-4373, ISBN 978-0-12-227055-0.

2. Abreu, P.P.; Souza, M.M.; Santos, E.A.; Pires, M.V.; Pires, M.M.; de Almeida, A.-A.F. Passion flower hybrids and their use in the ornamental plant market: Perspectives for sustainable development with emphasis on Brazil. Euphytica 2009, 166, 307-315. [CrossRef]

3. Ingale, A.G.; Hivrale, A.U. Pharmacological studies of Passiflora sp. and their bioactive compounds. Afr. J. Plant Sci. $2010,4,10$.

4. Shah, J.J.; Dave, Y.S. Tendrils of Passiflora foetida: Histogenesis and morphology. Am. J. Bot. 1970, 57, 786-793. [CrossRef]

5. Simpson, M.G. 8-Diversity and classification of flowering plants: Eudicots. In Plant Systematics, 2nd ed.; Simpson, M.G., Ed.; Academic Press: San Diego, CA, USA, 2010; pp. 275-448, ISBN 978-0-12-374380-0.

6. Ulmer, T.; MacDougal, J.M. Passiflora: Passionflowers of the World; Timber Press: Portland, OR, USA, 2004; ISBN 0-88192-648-5.

7. Moraes, A.M.; Milward-de-Azevedo, M.A.; Menini Neto, L.; de Faria, A.P.G. Distribution patterns of Passiflora L. (Passifloraceae s.s.) in the Serra Da Mantiqueira, Southeast Brazil. Braz. J. Bot. 2020, 43, 999-1012. [CrossRef]

8. Casierra-Posada, F.; Jarma-Orozco, A. Chapter 22-Nutritional composition of Passiflora Species. In Nutritional Composition of Fruit Cultivars; Simmonds, M.S.J., Preedy, V.R., Eds.; Academic Press: San Diego, CA, USA, 2016; pp. 517-534, ISBN 978-0-12-408117-8.

9. Silva, M.A.A.; Souza, M.M.; Silva, G.S.; Melo, C.A.F.; Corrêa, R.X.; Araújo, I.S.; Conceição, L.D.H.C.S. Analysis of transferability of microsatellite primers (SSR) in wild Passiflora species and intraspecific genetic diversity in Passiflora alata. Genet. Mol. Res. 2014, 13, 5908-5918. [CrossRef]

10. Vianna, L.S.; Pereira, T.N.S.; Santos, E.A.; Viana, A.P.; Pereira, M.G.; Ramos, H.C.C.; Rossi, A.A.B. Research article ISSR and SSR markers for determining genetic relationships among three wild species of Passiflora. Genet. Mol. Res. 2019, 18. [CrossRef]

11. De Santana, F.C.; Shinagawa, F.B.; Araujo, E.d.S.; Costa, A.M.; Mancini-Filho, J. Chemical composition and antioxidant capacity of Brazilian Passiflora seed oils. J. Food Sci. 2015, 80, C2647-C2654. [CrossRef] [PubMed]

12. Ramaiya, S.D.; Bujang, J.S.; Zakaria, M.H. Genetic diversity in Passiflora species assessed by morphological and ITS sequence analysis. Sci. World J. 2014, 2014, 598313. [CrossRef] [PubMed]

13. Rocha, D.; Batista, D.; Faleiro, F.; Rogalski, M.; Ribeiro, L.; Mercadante-Simões, M.; Yockteng, R.; Silva, M.; Soares, W.; Pinheiro, M.; et al. Passiflora spp. Passionfruit. In Biotechnology of Fruit and Nut Crops; Ritz, R., Ed.; CABI: London, UK, 2020; pp. 381-408, ISBN 978-1-78064-827-9.

14. Miroddi, M.; Calapai, G.; Navarra, M.; Minciullo, P.L.; Gangemi, S. Passiflora incarnata L.: Ethnopharmacology, clinical application, safety and evaluation of clinical trials. J. Ethnopharmacol. 2013, 150, 791-804. [CrossRef] [PubMed]

15. Porter-Utley, K.E. A revision of Passiflora L. subgenus Decaloba (DC.) Rchb. Supersection Cieca (Medik.) J. M. MacDougal \& Feuillet (Passifloraceae). PhytoKeys 2014, 43, 1. [CrossRef]

16. Sakalem, M.E.; Negri, G.; Tabach, R. Chemical composition of hydroethanolic extracts from five species of the Passiflora genus. Rev. Bras. Farmacogn. 2012, 22, 1219-1232. [CrossRef]

17. He, X.; Luan, F.; Yang, Y.; Wang, Z.; Zhao, Z.; Fang, J.; Wang, M.; Zuo, M.; Li, Y. Passiflora edulis: An insight into current researches on phytochemistry and pharmacology. Front. Pharmacol. 2020, 11, 617. [CrossRef] [PubMed]

18. Ni, Y.-W.; Lin, K.-H.; Chen, K.-H.; Wu, C.-W.; Chang, Y.-S. Flavonoid compounds and photosynthesis in Passiflora plant leaves under varying light intensities. Plants 2020, 9, 633. [CrossRef]

19. Patil, A.S.; Lade, B.D.; Paikrao, H.M. A scientific update on Passiflora foetida. Eur. J. Med. Plants 2015, 5, 145-155. [CrossRef] 
20. Song, Y.; Wei, X.-Q.; Li, M.-Y.; Duan, X.-W.; Sun, Y.-M.; Yang, R.-L.; Su, X.-D.; Huang, R.-M.; Wang, H. Nutritional composition and antioxidant properties of the fruits of a chinese wild Passiflora foetida. Molecules 2018, 23, 459. [CrossRef] [PubMed]

21. Zibadi, S.; Watson, R.R. Passion fruit (Passiflora edulis). Evid. Based Integr. Med. 2004, 1, 183-187. [CrossRef]

22. Gunathilake, K.D.P.P.; Ranaweera, K.K.D.S.; Rupasinghe, H.P.V. Influence of boiling, steaming and frying of selected leafy vegetables on the in vitro anti-inflammation associated biological activities. Plants 2018, 7, 22. [CrossRef] [PubMed]

23. Scorza, L.C.T.; Hernandes-Lopes, J.; Melo-de-Pinna, G.F.A.; Dornelas, M.C. Expression patterns of Passiflora edulis APETALA1/FRUITFULL homologues shed light onto tendril and corona identities. EvoDevo 2017, 8, 3. [CrossRef]

24. Tripathi, P.C. Passion fruit. In Horticultural Crops of High Nutraceutical Values; Peter, K.V., Ed.; Brillion Publishing: New Delhi, India, 2018; pp. 245-270, ISBN 978-93-87445-10-9.

25. Das, M.R.; Hossain, T.; Mia, M.A.B.; Ahmed, J.U.; Karim, A.J.M.S.; Hossain, M.M. Blooming pattern of passion fruit flower (Passiflora edulis Sims.) under diversified flashes. Am. J. Agric. Biol. Sci. 2013, 8. [CrossRef]

26. Dhawan, K.; Dhawan, S.; Sharma, A. Passiflora: A review update. J. Ethnopharmacol. 2004, 94, 1-23. [CrossRef]

27. Hemingway, C.A.; Christensen, A.R.; Malcomber, S.T. B- and C-Class Gene Expression during corona development of the blue passionflower (Passiflora caerulea, Passifloraceae). Am. J. Bot. 2011, 98, 923-934. [CrossRef]

28. Patel, S. Morphology and pharmacology of Passiflora edulis: A review. J. Herb. Med. Toxicol. 2009, 3, 1-6.

29. Vanderplank, J. Passion Flowers, 3rd ed.; MIT Press: Cambridge, MA, USA, 2000; ISBN 978-0-262-72035-9.

30. Kishore, K.; Pathak, K.A.; Shukla, R.; Bharali, R. Studies on floral biology of passion fruit (Passiflora spp.). Pak. J. Bot. 2010, 42, 21-29.

31. Das, M.R.; Hossain, T.; Mia, M.A.B.; Ahmed, J.U.; Kariman, A.J.M.S.; Hossain, M.M. Fruit setting behaviour of passion fruit. Am. J. Plant Sci. 2013, 4, 1066-1073. [CrossRef]

32. de Souza, M.M.; Pereira, T.N.S.; Hoffmann, M.; de Melo, E.J.T.; Louro, R.P. Embryo sac development in yellow passion fruit Passiflora edulis f. flavicarpa (Passifloraceae). Genet. Mol. Biol. 2002, 25, 471-475. [CrossRef]

33. Ickert-Bond, S.M.; Gerrath, J.; Wen, J. Gynoecial structure of Vitales and implications for the evolution of placentation in the Rosids. Int. J. Plant Sci. 2014, 175, 998-1032. [CrossRef]

34. Endress, P.K. Angiosperm ovules: Diversity, development, evolution. Ann. Bot. 2011, 107, 1465-1489. [CrossRef]

35. Ferrandiz, C. Fruit structure and diversity. In Encyclopedia of Life Sciences; John Wiley \& Sons Ltd.: Chichester, UK, 2011; ISBN 978-0-470-01590-2.

36. Faleiro, F.G.; Junqueira, N.T.V.; Junghans, T.G.; de Jesus, O.N.; Miranda, D.; Otoni, W.C. Advances in passion fruit (Passiflora spp.) Propagation. Rev. Bras. Frutic. 2019, 41, e155. [CrossRef]

37. Oliveira, I.S.d.S.; de Souza, V.C.; Santos, S.B.d.C.; Almeida, J.N.d.R.; Henrique, J.d.S.; Costa, P.M.d.A.; Silva, J.H.C.S.; Cassimiro, C.A.L.; de Lucena, C.É.A.; Melo, T.d.S. Floral biology and pollen viability of Passiflora edulis Sims. J. Exp. Agric. Int. 2019, 41, 1-9. [CrossRef]

38. Hopping, M.E. Structure and development of fruit and seeds in Chinese gooseberry (Actinidia chinensis Planch.). N. Z. J. Bot. 1976, 14, 63-68. [CrossRef]

39. Silva, K.R.; Stützel, T.; Oriani, A. Seed development and its relationship to fruit structure in species of Bromelioideae (Bromeliaceae) with fleshy fruits. Bot. J. Linn. Soc. 2020, 192, 868-886. [CrossRef]

40. Dauelsberg, P.; Matus, J.T.; Poupin, M.J.; Leiva-Ampuero, A.; Godoy, F.; Vega, A.; Arce-Johnson, P. Effect of pollination and fertilization on the expression of genes related to floral transition, hormone synthesis and berry development in grapevine. J. Plant Physiol. 2011, 168, 1667-1674. [CrossRef] [PubMed]

41. Kühn, N.; Arce-Johnson, P. Pollination: A key event controlling the expression of genes related to phytohormone biosynthesis during grapevine berry formation. Plant Signal. Behav. 2012, 7, 7-11. [CrossRef]

42. Shinozaki, Y.; Beauvoit, B.P.; Takahara, M.; Hao, S.; Ezura, K.; Andrieu, M.-H.; Nishida, K.; Mori, K.; Suzuki, Y.; Kuhara, S.; et al. Fruit setting rewires central metabolism via gibberellin cascades. Proc. Natl. Acad. Sci. USA 2020, 117, 23970-23981. [CrossRef]

43. Li, B.-F.; Yu, S.-X.; Hu, L.-Q.; Zhang, Y.-J.; Zhai, N.; Xu, L.; Lin, W.-H. Simple culture methods and treatment to study hormonal regulation of ovule development. Front. Plant Sci. 2018, 9, 784. [CrossRef]

44. Cucinotta, M.; Di Marzo, M.; Guazzotti, A.; de Folter, S.; Kater, M.M.; Colombo, L. Gynoecium size and ovule number are interconnected traits that impact seed yield. J. Exp. Bot. 2020, 71, 2479-2489. [CrossRef] [PubMed]

45. Kawamoto, N.; Del Carpio, D.P.; Hofmann, A.; Mizuta, Y.; Kurihara, D.; Higashiyama, T.; Uchida, N.; Torii, K.U.; Colombo, L.; Groth, G.; et al. A peptide pair coordinates regular ovule initiation patterns with seed number and fruit size. Curr. Biol. 2020, 30, 4352-4361.e4. [CrossRef] [PubMed]

46. Varga, A.; Bruinsma, J. Roles of seeds and auxins in tomato fruit growth. Z. Für Pflanzenphysiol. 1976, 80, 95-104. [CrossRef]

47. Doi, K.; Nozaki, R.; Takahashi, K.; Iwasaki, N. Effects of the number of seeds per berry on fruit growth characteristics, especially on the duration of stage II in blueberry. Plants 2018, 7, 96. [CrossRef]

48. Marcelis, L.F.M.; Baan Hofman-Eijer, L.R. Effects of seed number on competition and dominance among fruits in Capsicum annuum L. Ann. Bot. 1997, 79, 687-693. [CrossRef]

49. Stephenson, A.G.; Devlin, B.; Horton, J.B. The effects of seed number and prior fruit dominance on the pattern of fruit production in Cucurbits pepo (Zucchini squash). Ann. Bot. 1988, 62, 653-661. [CrossRef]

50. Vidal, M.d.G.; de Jong, D.; Wien, H.C.; Morse, R.A. Pollination and fruit set in pumpkin (Cucurbita pepo) by honey bees. Braz. J. Bot. 2010, 33, 106-113. [CrossRef] 
51. Sonkoly, J.; Vojtkó, E.A.; Tökölyi, J.; Török, P.; Sramkó, G.; Illyés, Z.; Molnár , V.A. Higher seed number compensates for lower fruit set in deceptive orchids. J. Ecol. 2016, 104, 343-351. [CrossRef]

52. Chiarini, F.E.; Barboza, G.E. Placentation patterns and seed number in fruits of South American Solanum subgen. Leptostemonum (Solanaceae) species. Darwiniana 2007, 45, 163-174. [CrossRef]

53. Rajan, S.; Yadava, L.P.; Kumar, R.; Saxena, S.K. Direct and indirect effects of seed related characters on number of seed in guava (Psidium guajava L.) Fruits. Sci. Hortic. 2008, 116, 47-51. [CrossRef]

54. López-Palacios, C.; Peña-Valdivia, C.B.; Reyes-Agüero, J.A.; Aguirre-Rivera, J.R.; Ramírez-Tobías, H.M.; Soto-Hernández, R.M.; Jiménez-Bremont, J.F. Inter- and intra-specific vriation in fruit biomass, number of seeds, and physical characteristics of seeds in Opuntia spp., Cactaceae. Genet. Resour. Crop Evol. 2015, 62, 1205-1223. [CrossRef]

55. Boavida, L.C.; Vieira, A.M.; Becker, J.D.; Feijo, J.A. Gametophyte interaction and sexual reproduction: How plants make a zygote. Int. J. Dev. Biol. 2004, 49, 615-632. [CrossRef]

56. Simpson, M.G. 9-Plant morphology. In Plant Systematics, 2nd ed.; Simpson, M.G., Ed.; Academic Press: San Diego, CA, USA, 2010; pp. 451-513. ISBN 978-0-12-374380-0.

57. Amela García, M.T.; Miguez, M.B.; Gottsberger, G. Pollen: Ovule ratio and its relationship with other reproductive traits in some Passiflora species (Passifloraceae). An. Jardín Botánico Madr. 2014, 71, e009. [CrossRef]

58. Martarello, N.S.; Gruchowski-Woitowicz, F.C.; Agostini, K. Pollinator efficacy in yellow passion fruit (Passiflora edulis f. flavicarpa Deg., Passifloraceae). Neotrop. Entomol. 2021, 50, 349-357. [CrossRef] [PubMed]

59. Nadeau, J.A.; Zhang, X.S.; Li, J.; O’Neill, S.D. Ovule development: Identification of stage-specific and tissue-specific cDNAs. Plant Cell 1996, 8, 213-239. [CrossRef] [PubMed]

60. Bencivenga, S.; Colombo, L.; Masiero, S. Cross talk between the sporophyte and the megagametophyte during ovule development. Sex. Plant Reprod. 2011, 24, 113-121. [CrossRef]

61. Lazarte, J.E.; Palser, B.F. Morphology, vascular anatomy and embryology of pistillate and staminate flowers of Asparagus officinalis. Am. J. Bot. 1979, 66, 753-764. [CrossRef]

62. Pinto, S.C.; Mendes, M.A.; Coimbra, S.; Tucker, M.R. Revisiting the female germline and its expanding toolbox. Trends Plant Sci. 2019, 24, 455-467. [CrossRef]

63. Robinson-Beers, K.; Pruitt, R.E.; Gasser, C.S. Ovule development in wild-type arabidopsis and two female-sterile mutants. Plant Cell 1992, 4, 1237-1249. [CrossRef]

64. Pérez-Pastrana, J.; Islas-Flores, I.; Bárány, I.; Álvarez-López, D.; Canto-Flick, A.; Canto-Canché, B.; Peña-Yam, L.; Muñoz-Ramírez, L.; Avilés-Viñas, S.; Testillano, P.S.; et al. Development of the ovule and seed of habanero chili pepper (Capsicum chinense Jacq.): Anatomical characterization and immunocytochemical patterns of pectin methyl-esterification. J. Plant Physiol. 2018, $230,1-12$. [CrossRef]

65. Brzezicka, E.; Kozieradzka-Kiszkurno, M. Female gametophyte development in Sedum sediforme (Jacq.) Pau (Crassulaceae): An anatomical, cytochemical and ultrastructural analysis. Protoplasma 2019, 256, 537-553. [CrossRef] [PubMed]

66. Liu, J.; Luo, Q.; Zhang, X.; Zhang, Q.; Cheng, Y. Identification of vital candidate microRNA/mRNA pairs regulating ovule development using high-throughput sequencing in hazel. BMC Dev. Biol. 2020, 20, 13. [CrossRef] [PubMed]

67. Yang, Y.; Sun, J.; Guo, X.; Wang, K.; Liu, Q.; Liu, Q. Anther and ovule development of Clematis serratifolia (Ranunculaceae)-with new formation types in megaspore and nucellus. PLoS ONE 2020, 15, e0240432. [CrossRef]

68. Xu, G.; Huang, J.; Lei, S.; Sun, X.; Li, X. Comparative gene expression profile analysis of ovules provides insights into Jatropha curcas L. ovule development. Sci. Rep. 2019, 9, 15973. [CrossRef]

69. de Moura, S.M.; Rossi, M.L.; Artico, S.; Grossi-de-Sa, M.F.; Martinelli, A.P.; Alves-Ferreira, M. Characterization of floral morphoanatomy and identification of marker genes preferentially expressed during specific stages of cotton flower development. Planta 2020, 252, 71. [CrossRef] [PubMed]

70. Halbritter, H.; Silvia, U.; Grímsson, F.; Weber, M.; Zetter, R.; Hesse, M.; Buchner, R.; Svojtka, M.; Frosch-Radivo, A. Illustrated Pollen Terminology; Springer International Publishing: Cham, Switzerland, 2018; ISBN 978-3-319-71364-9.

71. Dokland, T.; Hutmacher, D.W.; Ng, M.M.-L.; Schantz, J.-T. Techniques in Microscopy for Biomedical Applications; Manuals in Biomedical Research; World Scientific: Singapore, 2006; Volume 2, ISBN 978-981-256-434-4.

72. Fos, M.; Nuez, F.; Garcia-Martınez, J.L. The gene Pat-2, which induces natural parthenocarpy, alters the gibberellin content in unpollinated tomato ovaries. Plant Physiol. 2000, 122, 471-480. [CrossRef]

73. Moreno-Sanz, P.; D'Amato, E.; Nebish, A.; Costantini, L.; Grando, M.S. An optimized histological proceeding to study the female gametophyte development in grapevine. Plant Methods 2020, 16, 61. [CrossRef]

74. Lynch, S.P.; Webster, G.L. A new technique of preparing pollen for scanning electron microscopy. Grana 1975, 15, 127-136. [CrossRef]

75. Dustmann, J.H.; von der Ohe, K. Scanning electron microscopic studies on pollen from honey. IV. surface pattern of pollen of Sapium sebiferum and Euphorbia spp. (Euphorbiaceae). Apidologie 1993, 24, 59-66. [CrossRef]

76. Pathan, A.K.; Bond, J.; Gaskin, R.E. Sample preparation for SEM of plant surfaces. Mater. Today 2010, 12, 32-43. [CrossRef]

77. Garcia, M.T.A.; Galati, B.G.; Anton, A.M. Microsporogenesis, microgametogenesis and pollen morphology of Passiflora spp. (Passifloraceae). Bot. J. Linn. Soc. 2002, 139, 383-394. [CrossRef]

78. Kim, H.N. Comparative study of immune-enhancing activity of crude and mannoprotein-free yeast-glucan preparations. J. Microbiol. Biotechnol. 1999, 9, 826-831. 
79. Hartig, S.M. Basic image analysis and manipulation in ImageJ. Curr. Protoc. Mol. Biol. 2013, 102, 14.15.1-14.15.12. [CrossRef]

80. Mochizuki, J.; Itagaki, T.; Blue, Y.A.; Ito, M.; Sakai, S. Ovule and seed production patterns in relation to flower size variations in actinomorphic and zygomorphic flower species. AoB Plants 2019, 11,1-8. [CrossRef]

81. Radhamani, T.R.; Sudarshana, L.; Krishnan, R. Defense and carnivory: Dual role of bracts in Passiflora foetida. J. Biosci. 1995, 20, 657-664. [CrossRef]

82. Acevedo-Rodríguez, P. Vines and Climbing Plants of Puerto Rico and the Virgin Islands; Department of Botany, National Museum of Natural History: Washington, DC, USA, 2005; Volume 51.

83. Colombo, L.; Battaglia, R.; Kater, M.M. Arabidopsis ovule development and its evolutionary conservation. Trends Plant Sci. 2008, 13, 444-450. [CrossRef] [PubMed]

84. Gaiser, J.C.; Robinson-Beers, K.; Gasser, C.S. The Arabidopsis SUPERMAN gene mediates asymmetric growth of the outer integument of ovules. Plant Cell 1995, 7, 333-345. [CrossRef] [PubMed]

85. Gillaspy, G.; Ben-David, H.; Gruissem, W. Fruits: A developmental perspective. Plant Cell 1993, 5, 1439-1451. [CrossRef] [PubMed]

86. Padhye, M.D.; Deshpande, B.G. The male and female gametophytes of Passiflora foetida Linn. Proc. Indian Acad. Sci. Sect. B 1960, 52, 124-130. [CrossRef]

87. Drews, G.N.; Koltunow, A.M.G. The female gametophyte. Arab. Book 2011, 9, e0155. [CrossRef]

88. Greenway, C.A.; Harder, L.D. Variation in ovule and seed size and associated size-number trade-offs in angiosperms. Am. J. Bot. 2007, 94, 840-846. [CrossRef]

89. Colle, M.; Weng, Y.; Kang, Y.; Ophir, R.; Sherman, A.; Grumet, R. Variation in cucumber (Cucumis sativus L.) fruit size and shape results from multiple components acting pre-anthesis and post-pollination. Planta 2017, 246, 641-658. [CrossRef]

90. Wetzstein, H.Y.; Yi, W.; Porter, J.A.; Ravid, N. Flower position and size impact ovule number per flower, fruitset, and fruit size in pomegranate. J. Am. Soc. Hortic. Sci. 2013, 138, 159-166. [CrossRef]

91. Strelin, M.M.; Aizen, M.A. The interplay between ovule number, pollination and resources as determinants of seed set in a modular plant. PeerJ 2018, 6, e5384. [CrossRef]

92. Singh, K.; Sharma, Y.P.; Sharma, P.R.; Gairola, S. Pollen morphology and variability of the Rosa L. species of Western Himalaya in India. Genet. Resour. Crop Evol. 2020, 67, 2129-2148. [CrossRef] 